\title{
CONSUMERS' AWARENESS OF THEIR RIGHTS WHEN SHOPPING FOR FOOD ONLINE AMONG PEOPLE AGED OVER 45
}

\author{
Irena Ozimek, Full Professor ${ }^{* *}$; Julita Szlachciuk, $\mathrm{PhD}^{2^{* *}}$ \\ ${ }^{1}$ Faculty of Economic Sciences, Warsaw University of Life Sciences - SGGW \\ ${ }^{2}$ Faculty of Human Nutrition and Consumer Sciences, Warsaw University of Life Sciences - SGGW \\ ${ }^{*}$ https://orcid.org/0000-0003-3430-8276 \\ ${ }^{* *}$ https://orcid.org/0000-0002-9742-2044
}

\begin{abstract}
The aim of the article is to assess the awareness of consumer rights among people shopping for food online. The study was carried out on 529 respondents shopping for food online. The obtained results showed that the majority of the respondents assess their awareness of consumer rights in the purchase of food online as good. Nevertheless, part of the respondents failed to unequivocally and clearly respond to statements concerning the level of their awareness. The study findings indicate the need for education in the consumer rights of people shopping for food online. This seems to be particularly justified in light of growing interest in online shopping, including online shopping for food.
\end{abstract}

Key words: consumers, e-commerce, food law

JEL codes: K15, D18

\section{INTRODUCTION}

The number of online shops in Poland keeps growing from year to year. The data collected by Bisnode reveal that approximately 31,000 of such shops were registered in Poland at the end of 2018. This constituted a rise of over $6.1 \%$ in comparison with the 2017 figure (Bisnode Polska, 2019).

A report of Nielsen Services Poland, a market research company, reveals that sales of FMCGs (fast-moving consumer goods) online are rising four times faster than their offline sales. What seems to underpin the trend is, among others, the ever faster pace of private and professional life and the growing popularity of the so-called convenience trend
(Nielsen, 2018b). The results of research conducted by the Statistcs Poland (Polish acronym GUS) show that in 2018 approximately $1 / 4$ of consumers purchased foodstuffs and cosmetics ${ }^{3}$ online (Statistcs Poland, 2018). According to the report "E-commerce w Polsce 2018", online purchases are made mainly by young educated people, residents of bigger towns, describing their financial situation as good (Gemius, 2018). On the other hand, this form of shopping seems to be gaining ever greater interest among the elderly. The findings of the study made by the ARC Rynek i Opinia Market Research Agency reveal that over $1 / 3$ of respondents over the age of 57 want to spend more money online shopping (Portal slowoseniora.pl, n.d.).

\footnotetext{
${ }^{1}$ Corresponding author: Nowoursynowska 166, 02-787 Warsaw, Poland, irena_ozimek@sggw.pl, +4822 5934187

${ }^{2}$ Corresponding author: Nowoursynowska 159c, 02-776 Warsaw, Poland, julita_szlachciuk@sggw.pl, +4822 5937132

${ }^{3}$ Figures for foodstuffs alone were not made available.
} 
Earlier studies carried out by Gemius reported that online shopping consumers seek information on food products mostly on web pages of traditional shops and via Internet browsers. The most common factor discouraging Internet users from buying food online is their concern about the freshness of products and lack of a possibility to see or touch them. Respondents also pointed to other potential barriers to online shopping for food, namely, the high cost of delivery and the long waiting time related to the delivery (Gemius, 2014).

What should be emphasized is that the general regulations of consumer and food law apply to both the food sold online and the food purchased in the traditional way, at all stages of food production, processing and distribution. An important solution concerning distance selling was introduced by the Act of 30 May 2014 on Consumer Rights and the Regulation (EU) 1169/2011 on the provision of consumers with information on food. It is entrepreneurs involved in online sales that are to bear responsibility for providing consumers with reliable information.

It is worth mentioning that the European Commission is in the process of preparing a draft of amendments ("New deal for consumers") aimed at ensuring better protection of consumer rights in general and online shopping consumers in particular. The draft provides, among others, for the introduction of a new information obligation in online transactions. The consumer will have to be informed about who they are performing a legal act with, i.e. whether with the entrepreneur or with another entity. The postulated change is intended to ensure the consumer a possibility to see whether in a given transaction the consumer is protected by the rights the consumer is entitled to where a transaction is between an entrepreneur and a consumer (Podrecki et al., 2018).

\section{MATERIALS AND METHODS}

The study was carried out in November 2016 on a randomly selected sample of 529 Polish residents aged over $45^{4}$. The selection of the study sample involved the selection of typical respondents which consisted in choosing a respondent group from among people shopping for food online. The research agency to carry out the study was selected through a bidding procedure. The study used the CATI (computer assisted telephone inquiries) method.

The study was conducted with the use of a questionnaire prepared by the author. The questions concerning respondents' demographics allowed for characterizing them in terms of features such as: sex, age, education, place of residence and financial status. The obtained results were processed statistically. Nonparametric $\mathrm{Chi}^{2}$ Pearson test was used to examine the statistical significance of the differences. Spearman's rank correlation coefficient was applied to analyse dependence between two variables expressed on an ordinal scale. A statistical significance level of $\alpha=0.05$ was adopted.

\section{RESULTS AND DISCUSSION}

The study sample consisted of a total of 529 people and included 194 people aged 45-49 (36.7\%, 174 people aged 50-54 (32.9\%), 90 people aged 55-59 $(17.0 \%)$ and 71 people aged 60-64 (13.4\%). Women constituted $50.5 \%$ of the studied population sample. The respondents were inhabitants of both rural and urban centres. Inhabitants of towns with a population of over 100,000 accounted for $27.2 \%$ of the study sample. Barely every $5^{\text {th }}$ respondent was a resident of a rural area (Table 1).

More than $40 \%$ of the respondents declared doing online shopping for food once a month and over $1 / 3$ admitted doing it a few times a year. Every $10^{\text {th }}$ respondent reported making online food purchases once a week.

Asked about their assessment of their awareness of the rights of online food buyers, almost a half of the respondents declared their awareness of them to be good or very good. In turn, $39.5 \%$ of the respondents assessed their knowledge as limited. Only as few as $4.7 \%$ of the respondents admitted having little knowledge of the subject. Men and people with higher education declared a higher knowledge of the subject, $79.6 \%$ and $78.2 \%$, respectively. As regards

${ }^{4}$ Findings concerning young consumers and their awareness of their rights were described in another article. 
Proceedings of the 2019 International Scientific Conference 'Economic Sciences for Agribusiness and Rural Economy' No 3, Warsaw, 5-7 June 2019, pp. 89-94

Table 1. Demographic characteristics of respondents

\begin{tabular}{|l|l|c|}
\hline Variables & $\%$ \\
\hline \multirow{4}{*}{ Gender } & women & 50.5 \\
\cline { 2 - 3 } & men & 49.5 \\
\hline \multirow{4}{*}{ Age } & $45-49$ years & 36.7 \\
\cline { 2 - 3 } & $50-54$ years & 32.9 \\
\cline { 2 - 3 } & $55-59$ years & 17.0 \\
\hline \multirow{5}{*}{ Education } & 60-64 years & 13.4 \\
\hline \multirow{5}{*}{ Locality } & elementary and vocational & 19.6 \\
\cline { 2 - 3 } & secondary & 40.1 \\
\cline { 2 - 3 } & university & 40.3 \\
\hline & rural & 17.8 \\
\cline { 2 - 3 } & urban, up to 50000 & 26.1 \\
\cline { 2 - 3 } & urban, 50 000 to 100.000 & 2.9 \\
\cline { 2 - 3 } & urban, over 100000 & 27.2 \\
\hline
\end{tabular}

Source: own research.

education, the dependence was statistically significant. The need of the awareness of consumer rights in the area of online food purchases gains significance when we look at the European Commission data assessing the situation of consumers in the EU. Poland recorded the poorest results as regards the observance and execution of regulations concerning the protection of consumer rights. Research conducted among entrepreneurs revealed that, as a rule, entrepreneurs notice unfair market practices only when used by their competitors (Podrecki et al., 2018).
The analysis of the replies of the respondents to individual statements concerning online purchases showed that over $3 / 4$ of the respondents declared trust in the good quality of online sold food (Table 2). The trust was more frequently expressed by women and people aged 50-54. In terms of gender, this dependence was statistically significant $\left(\mathrm{Chi}^{2} ; \mathrm{p} \geq 0.05\right)$. A high level of consumer trust was also recorded with respect to the procedure of placing online orders. Trust in this respect was more frequently declared by women $\left(\mathrm{Chi}^{2} ; \mathrm{p} \geq 0.05\right)$. Research conducted among

Table 2. Responses to selected statements relating to the purchase of food

\begin{tabular}{|l|c|c|c|}
\hline \multirow{2}{*}{ Variables } & \multicolumn{2}{|c|}{ Answer (\%) } \\
\cline { 2 - 4 } & $\begin{array}{c}\text { strongly agree } \\
\text { and agree }\end{array}$ & undecided & $\begin{array}{c}\text { disagree and strong- } \\
\text { ly disagree }\end{array}$ \\
\hline I have trust in the quality of online sold food & 77.5 & 18.7 & 3.8 \\
\hline I have trust in the rules of online order placement & 74.1 & 23.4 & 2.5 \\
\hline $\begin{array}{l}\text { Access to information about the rules of lodging claims } \\
\text { is easier in the case of online food purchases }\end{array}$ & 68.1 & 25.5 & 6.4 \\
\hline
\end{tabular}

Source: own research. 
Ceneo.pl Service clients revealed that $65 \%$ of people over 55 years of age consider online shopping as at least equally safe as traditional shopping (Portal slowoseniora.pl, n.d.).

The Nielsen Market Research Company report showed that consumers are becoming ever more open to online shopping for food, among others, when the quality of the purchased products is guaranteed. Approximately $50 \%$ of consumers would feel more encouraged to online food purchases if they had a guarantee of a refund of money for products which do not correspond to the ordered ones (Nielsen, 2018a).

Every $4^{\text {th }}$ respondent found responding to the statement "Access to information about the rules of lodging claims is easier in the case of online food purchases" difficult. Czarnecka (2017) remarks that the scale of seeking information by consumers depends, among others, on how much they need the information to satisfy their needs or on the availability of different data sources. Eurostat research revealed that one of the problems most frequently reported by EU consumers were, among others, difficulties related to placing a claim and receiving a reply to a claim (Eurostat, 2017).

In the question which followed, the respondents were asked to respond to five statements the aim of which was to see their awareness of the rights of the online food-buying consumer (Table 3 ). The respondents had the least problem with giving a correct answer to the statement "every online shop should have the rules of work placed on their web page". A statistically significant response to this statement was given more frequently by respondents aged $50-54\left(\mathrm{Chi}^{2}\right.$; $p \geq 0.05$ ). Over $80 \%$ of the respondents knew that a distance contract can be cancelled within 14 days without giving a reason. The highest level of awareness in this respect was shown also by the respondents aged 50-54. In turn, every $5^{\text {th }}$ respondent was not able to respond to the statement "if a consumer cancels a distance contract, he also bears the cost of the goods being sent back to the entrepreneur", and every $4^{\text {th }}$ respondent was not able to unequivocally state whether "access to information about the claimlodging rules is easier in the case of online food purchases".

The statistical analysis with the use of Spearman's rank correlation coefficient showed the existence of weak, positive dependence between the respondents' awareness of selected rights of consumers shopping for food online and their subjective assessment of their general awareness of consumer rights in online food purchases (Table 4).

The results show that in spite of the fact that the majority of the respondents assess their awareness of their rights as very good or good, it is not always

Table 3. Awareness of the individual rights of consumers making online food purchases

\begin{tabular}{|c|c|c|c|c|}
\hline \multirow[b]{2}{*}{ Variables } & \multirow[b]{2}{*}{ Correct answer } & \multicolumn{3}{|c|}{ Answer (\%) } \\
\hline & & $\begin{array}{l}\text { strongly agree } \\
\text { and agree }\end{array}$ & undecided & $\begin{array}{c}\text { disagree and } \\
\text { strongly disagree }\end{array}$ \\
\hline $\begin{array}{l}\text { Every online shop should have their rules of } \\
\text { work placed on their web pages }\end{array}$ & true & 95.6 & 3.6 & 0.8 \\
\hline $\begin{array}{l}\text { A distance contract can be cancelled without } \\
\text { giving a reason within } 14 \text { days }\end{array}$ & true & 83.7 & 14.6 & 1.7 \\
\hline $\begin{array}{l}\text { If a consumer cancels a distance contract, the } \\
\text { consumer bears also the cost of the goods } \\
\text { being sent back to the entrepreneur }\end{array}$ & true & 73.3 & 20.4 & 6.3 \\
\hline $\begin{array}{l}\text { Food sold online is subject to the same } \\
\text { control as food sold in traditional shops }\end{array}$ & true & 70.7 & 24.2 & 5.1 \\
\hline
\end{tabular}

Source: own research. 
Table 4. Dependence between the assessment of the awareness of the rights and the awareness of selected food-selling rules

\begin{tabular}{|l|c|}
\hline \multirow{2}{*}{ Variables } & Value of Spearman's rank correlation coefficient \\
\cline { 2 - 2 } & Level of the awareness of the rights \\
\hline $\begin{array}{l}\text { A distance contract can be cancelled without giving a reason within } \\
14 \text { days }\end{array}$ & $0.263^{*}$ \\
\hline $\begin{array}{l}\text { Food sold online is subject to the same control as food sold } \\
\text { in traditional shops }\end{array}$ & $0.235^{*}$ \\
\hline $\begin{array}{l}\text { If a consumer cancels a distance contract, the consumer bears also } \\
\text { the cost of the goods being sent back to the entrepreneur }\end{array}$ & $0.164^{*}$ \\
\hline $\begin{array}{l}\text { Every online shop should have their rules of work placed on their } \\
\text { web pages }\end{array}$ & $0.146^{*}$ \\
\hline
\end{tabular}

$* \mathrm{p} \leq 0.01$.

Source: own research.

reflected in their actual knowledge of the subject. Czarnecka (2017) remarks that the multitude of information which has to be passed to consumers causes that they can feel disoriented. On the one hand, it is necessary to provide them with obligatory information and, on the other, we are facing an information overload which requires from customers being able to orient themselves in the environment in conditions of excess information.

\section{CONCLUSIONS}

The study findings reveal growing legal awareness of consumers. The majority of the respondents were aware of consumer rights relating to online food shopping. Yet, part of the respondents was not able to unequivocally respond to the statements referring to the level of their awareness. The obtained results point to the necessity of educating consumers in their rights relating to online food purchases. The authors believe that in the educational effort emphasis should be put on developing skills necessary to successful, broadly understood information processing.

\section{Acknowledgements}

The study was carried out under an internal grant for young scientific workers (Grant 505-10-102500-N00331-99).

\section{REFERENCES}

1. Bisnode Polska (2019). Wzrost liczby sklepów internetowych w Polsce w 2018 roku [Increase in the number of online stores in Poland in 2018.]. Retrieved from: https:// www.bisnode.pl/wiedza/newsy-artykuly/wzrost-liczbysklepow-internetowych-w-polsce [Access 09.05.2019].

2. Czarnecka, M. (2017). Ekonomiczna analiza prawa ochrony konsumentów [Law \& economics of consumer protection]. Studia Ekonomiczne, 321, pp. 118-135.

3. European Commission (2017). Consumer conditions scoreboard: consumers at home in the single market. 2017 edn. Retrieved from: https://ec.europa.eu/info/ sites/info/files/consumer-conditions-scoreboard-2017edition_en_0.pdf [Access 17.05.2019].

4. Eurostat (2017). Retrieved from: http://ec.europa.eu/ eurostat/data/database [Access 27.05.2019].

5. Gemius (2014). e-Commerce w Polsce 2014 [e-Commerce in Poland 2014]. Retrieved from: http://infomonitorbig.eu/download/e-commerce-w-polsce-2014. pdf [Access 02.05.2019].

6. Gemius (2018). e-Commerce w Polsce 2018 [e-Commerce in Poland 2018]. Retrieved from: https://www. gemius.pl/e-commerce-aktualnosci/internauci-zaufali-e-sklepom-raport-e-commerce-w-polsce-2018-juzdostepny.html [Access 19.05.2019].

7. GUS [Statistics Poland] (2018). Społeczeństwo informacyjne w Polsce. Wyniki badań statystycznych z lat 2014-2018 [Information society in Poland. Results of statistical surveys in the years 2014-2018]. Warszawa - Szczecin. 
8. Nielsen (2018a). Connected commerce. Retrieved from: https://www.nielsen.com/content/dam/nielsenglobal/dk/docs/connected-commerce-report-2018.pdf [Access 20.05.2019].

9. Nielsen (2018b). Future Opportunities in FMCG e-commerce: market drivers and five-years forecast. Retrieved from: https://www.nielsen.com/content/dam/nielsenglobal/apac/docs/reports/2018/ future-opportunities-in-fmcg-ecommerce.pdf [Access 20.05.2019].

10. Podrecki, P. (ed.), Uchańska. J. (ed.), Wiese, K., Mroczek, M. (2018). Prawa konsumentów w Unii Europejskiej. Praktyczny poradnik dla przedsiębiorców [Consumer rights in the European Union. A practical guide for entrepreneurs]. PARP, Warszawa.

11. Portal slowoseniora.pl (n.d.). Co senior kupuje online? Raport [What does the senior purchase online? Report].
Retrieved from: https://slowoseniora.pl/co-senior-kupuje-online-raport [Access 27.05.2019].

12. Regulation (EU) No $1169 / 2011$ of the European Parliament and of the Council of 25 October 2011 on the provision of food information to consumers, amending Regulations (EC) No 1924/2006 and (EC) No $1925 / 2006$ of the European Parliament and of the Council, and repealing Commission Directive 87/250/EEC, Council Directive 90/496/EEC, Commission Directive 1999/10/EC, Directive 2000/13/EC of the European Parliament and of the Council, Commission Directives 2002/67/EC and 2008/5/EC and Commission Regulation (EC) No 608/2004 (Text with EEA relevance).

13. Ustawa $z$ dnia 30 maja 2014 roku o prawach konsumenta. Dz.U. 2019, poz 134, z późn. zm. [Act of 30 May 2014 on Consumer Rights. Journal of Laws 2019, Item 134, as amended]. 